\title{
PENGEMBANGAN BAHAN AJAR MATA KULIAH KALKULUS VEKTOR UNTUK MENINGKATKAN KEMAMPUAN BERPIKIR KRITIS MATEMATIS
}

\author{
T. Tutut Widiastuti A. \\ Program Studi Pendidikan Matematika UIN Sunan Gunung Djati Bandung \\ Jl. Cimencrang, Cimencrang, Panyileukan, Kota Bandung, Jawa Barat 40292
}

\begin{abstract}
This research aims to get the result of the development of teaching materials valid vector calculus courses and proving the effectiveness of learning. The development model that will be used to develop teaching materials in this study is Four-D Models (Model 4D). The results of the use of teaching materials in the Calculus Vector subjects are stated to be valid and effective. This valid is based on: Meet the validate content and constructs set by experts. Effective learning is stated in the following 4 things. (a) Students who use learning instructional materials developed achieve individual and classical learning, (b) The average student score in the experimental class is better than the control class, (c) The influence of students' attitudes and learning skills on abilities critical thinking, and (d) There is an increase in the ability to think critically in classes that use the development of teaching materials.
\end{abstract}

Keywords: Critical thinking; Vector calculus

\section{PENDAHULUAN}

Dalam menghadapi dunia yang penuh persaingan dan tantangan saat ini diperlukan sumber daya manusia yang memiliki kemampuan tinggi dalam memecahkan berbagai persoalan yang dihadapi. Seseorang yang memiliki kemampuan tinggi harus dapat berpikir logis, rasional, kritis dan kreatif. Kemampuan berpikir logis, rasional, kritis dan kreatif termasuk dalam kemampuan berfikir tingkat tinggi yang tidak dapat terjadi dengan sendirinya, melainkan diperoleh melalui proses pendidikan khususnya pendidikan matematika di sekolah (Abdullah, 2013).

Berkenaan dengan berpikir kritis, Wahab (1996) mengemukakan empat alasan pentingnya mengembangkan kemampuan berpikir kritis, yaitu: 1) tuntutan zaman yang mengharuskan warga negara dapat mencari, memilih, dan menggunakan informasi untuk kehidupan bermasyarakat dan bernegara; 2) setiap warga Negara senantiasa berhadapan dengan berbagai masalah dan pilihan sehingga dituntut untuk mampu berpikir kritis dan kreatif; 3) kemampuan memandang sesuatu dengan cara yang berbeda dalam memecahkan masalah; dan 4) berpikir kritis merupakan aspek dalam memecahkan permasalahan secara kreatif agar mahasiswa dapat bersaing secara adil dan mampu bekerja sama dengan bangsa 
lain. Dari empat alasan pentingnya mengembangkan kemampuan berpikir kritis disimpulkan bahwa kemampuan berpikir kritis dapat bermanfaat untuk menghadapi berbagai kemungkinan dan memiliki karakteristik yang paling mungkin dapat dikembangkan melalui pembelajaran matematika (Depdiknas, 2004).

Kemampuan berpikir kritis matematika adalah kemampuan berpikir pada ilmu matematika yang melibatkan pengetahuan matematika, penalaran matematika dan pembuktian matematika dalam menyelesaikan masalah matematika (Martomidjojo, 2018). Adapun pengetahuan, penalaran dan pembuktian di dalam matematika tersebut adalah untuk mencari, menyaring dan memanfaatkan informasi yang jelas dari setiap pernyataan, sehingga mampu menentukan solusi masalah atau mengambil keputusan berdasarkan konsep dan fakta yang ada. Dengan demikian terbentuk suatu rangkuman kesimpulan dari satu atau beberapa konsep/teorema/definisi yang akan digunakan. Berdasarkan hal tersebut, peneliti mendefinisikan kemampuan berpikir kritis matematika adalah kemampuan untuk merumuskan dan mengevaluasi keyakinan dan pendapat. Sehingga, ketika menjawab dan memecahkan suatu masalah disertai dengan alasan dan pendapat yang kuat yang didasari oleh analisis yang baik. Analisis dilakukan salah satunya dengan mempertimbangkan baik buruknya dan kelogisan setiap kemungkinan pemecahan masalah. Berpikir kritis matematika dapat membekali siswa untuk sebaik mungkin menghadapi informasi yang didengar, dibaca, dialami sendiri, dan keputusan yang dibuat setiap hari khususnya informasi melalui pembelajaran matematika dalam hal ini mata kuliah kalkulus vektor.

Kalkulus Vektor merupakan salah satu mata kuliah menempati posisi strategis untuk mengembangkan kemampuan berpikir kritis. Kalkulus Vektor berfungsi untuk mengembangkan kemampuan berpikir analitis, kritis, dan kreatif. Kalkulus Vektor juga penting bagi mahasiswa untuk meningkatkan wawasan matematis (Spiegel, 1985). Karena itu, argumentasi tersebut mendasari pemikiran bahwa kalkulus vektor perlu diajarkan di perguruan tinggi. Berdasarkan hasil observasi, dari 112 mahasiswa yang berasal dari 3 kelas, masih terdapat 37 mahasiswa (33\%) mendapatkan nilai $\mathrm{C}$ dan $\mathrm{D}$, bahkan ada beberapa mahasiswa yang masih mendapatkan nilai E (disebabkan dari faktor lain juga seperti absensi kehadiran). Oleh karena itu, peneliti menyimpulkan masih banyak mahasiswa kesulitan menyelesaikan masalah-masalah dalam materi kalkulus vektor yang mengakibatkan kualitas belajar cenderung menurun dan mengakibatkan kemampuan berpikir kritis sangat lemah.

Dari masalah tersebut (salinan oleh Bambang Sutedjo: 01) dan selaras dengan tuntutan kompetensi yang harus dimiliki pendidik (kompetensi pedagogik, kompetensi kepribadian, kompetensi sosial, dan kompetensi profesi), pengembangan bahan ajar (materi pembelajaran) 
merupakan salah satu kewajiban yang diemban pendidik untuk mengembangkan kompetensi yang dimiliki sehingga dapat meningkatkan eksistensinya sebagai pendidik yang profesional. Pemilihan bahan ajar terkait erat dengan silabus, yang di dalamnya terdapat standar kompetensi dan kompetensi dasar, materi pokok, pengalaman belajar, metode, evaluasi, dan sumber. Selaras dengan pengembangan silabus, maka materi pembelajaran yang akan dikembangkan sudah semestinya tetap memperhatikan pencapaian standar kompetensi dan kompetensi dasar, kesesuaian dengan materi pokok yang diajarkan, mendukung pengalaman belajar, ketepatan metode dan media pembelajaran, dan sesuai dengan indikator untuk mengembangkan asesmen.

Pedoman pengembangan bahan ajar ini merupakan rambu-rambu yang perlu diperhatikan ketika mengembangkan bahan ajar. Sejumlah manfaat yang dapat dipetik dari pedoman pengembangan bahan ajar ini bagi para pengembang bahan ajar diantaranya adalah untuk: (1) memperoleh gambaran tentang cara menganalisis bahan ajar yang akan diajarkan; (2) memperoleh gambaran tentang cara-cara analisis pedagogik yang akan diterapkan dalam pembelajaran; (3) dapat mengembangkan kemampuannya dalam mengelola bahan ajar; (4) lebih kritis menyesuaikan bahan ajar yang dikembangkannya dengan karakteristik peserta didik; (5) dapat mengembangkan kemampuannya dalam mengembangkan kurikulum; (6) berpeluang menjadi tenaga pendidik yang profesional terkait dengan kompetensi pedagogis, kompetensi profesi, kompetensi kepribadian dan kompetensi sosial.

Dari uraian diatas, maka dilakukan penelitian dengan tema pengembangan bahan ajar mata kuliah kalkulus vektor untuk meningkatkan kemampuan berpikir kritis matematis. Penelitian ini bertujuan untuk: (1) mendapatkan hasil pengembangan bahan ajar mata kuliah kalkulus vektor yang valid, dan (2) membuktikan keefektifan pembelajaran dengan pengembangan bahan ajar pada mata kuliah kalkulus vektor.

\section{METODE PENELITIAN}

Metode penelitian ini adalah jenis penelitian R \& D (research and development) atau jenis penelitian pengembangan. Pengembangan yang dilakukan adalah bahan ajar untuk meningkatkan kemampuan berpikir kritis matematis pada mata kuliah kalkulus vektor. Model yang akan digunakan untuk mengembangkan bahan ajar dalam penelitian ini adalah Four-D Models (Model 4D). Model 4D dipilih karena sistematis dan cocok untuk mengembangkan bahan ajar. Namun, dalam penelitian ini hanya dilakukan sampai pada tahap pengembangan tidak sampai pada tahap penyebaran. Hal ini dilakukan karena model 4D ini dirancang untuk pembelajaran bagi peserta 
didik luar biasa (exceptional pupils), sedangkan obyek penelitian ini adalah peserta didik biasa/normal.

Subyek uji coba dalam penelitian ini dilaksanakan di semester IV prodi Pendidikan Matematika tahun pelajaran 2017-2018 dengan memilih dua dari tiga kelas di semester tersebut. Pengambilan subyek uji coba dilaksanakan secara acak (random sampling) terhadap 3 kelas pararel yang berkemampuan setara terdiri dari 1 kelas uji coba dan dua kelas sampel yaitu 1 kelas sebagai kelas ekperimen dan 1 kelas sebagai kelas kontrol. Waktu penelitian dilaksanakan pada bulan Februari-Mei 2018.

Metode pengumpulan data yang digunakan dalam penelitian ini adalah: (1) metode tes, digunakan untuk mendapatkan nilai kemampuan berpikir kritis matematis pada mata kuliah kalkulus vector, (2) metode dokumentasi, dalam penelitian ini digunakan untuk memperoleh data-data tertulis tentang daftar nama mahasiswa untuk kelas eksperimen, untuk kelas kontrol dan untuk kelas uji coba soal, jumlah mahasiswa dan data lain mahasiswa pada kelas yang akan digunakan untuk kepentingan penelitian, (3) metode angket, digunakan untuk mengetahui respon dan sikap belajar siswa dalam mengikuti pembelajaran pada mata kuliah kalkulus vector, dan (4) metode observasi, digunakan untuk mengamati keterampilan mahasiswa selama mengikuti pembelajaran dan digunakan untuk mengamati kemampuan dosen dalam mengelola pembelajaran.

Teknik analisis data membahas tentang: (1) analisis hasil validasi bahan ajar, (2) analisis tes uji coba, (3) analisis data awal yang meliputi: uji homogenitas, normalitas, dan uji kesamaan rata-rata, dan (4) analisis data akhir serta analisis keefektifan pembelajaran meliputi: uji ketuntasan individu dan klasikal, uji pengaruh antara sikap dan keterampilan siswa terhadap kemampuan berpikir kritis, uji beda rata-rata dan analisis peningkatan tes kemampuan berpikir kritis.

\section{HASIL DAN PEMBAHASAN}

\section{Hasil validasi ahli}

Salah satu kriteria utama untuk menentukan dipakai tidaknya suatu bahan ajar adalah hasil validasi oleh ahli. Validasi ini dilakukan untuk melihat validitas isi dari draf 1 yang telah disusun dan disesuaikan dengan bahan ajar mata kuliah kalkulus vektor. Validasi dilakukan oleh reviewer dan dosen ahli kalkulus vektor untuk menilai kelayakan bahan ajar. 
Tabel 1. Rangkuman Revisi dari Reviewer dan Dosen Ahli

\begin{tabular}{lll}
\hline Bagian yang direvisi & Catatan validator & Tindak lanjut \\
\hline $\begin{array}{l}\text { Teknik Penulisan dan } \\
\text { tata Bahasa }\end{array}$ & $\begin{array}{l}\text { Gunakan istilah yang baku } \\
\text { dan gunakan kalimat pasif } \\
\text { (sesuaikan dengan pedoman } \\
\text { penyusunan bahan ajar) }\end{array}$ & $\begin{array}{l}\text { Perbaikan menggunakan istilah baku } \\
\text { dan kalimat pasif }\end{array}$ \\
\hline Isi bahan ajar & $\begin{array}{l}\text { Perbanyak gambar atau } \\
\text { lambang dalam bahasa } \\
\text { matematika }\end{array}$ & $\begin{array}{l}\text { Penambahan gambar yang } \\
\text { merupakan ilustrasi materi }\end{array}$ \\
\hline
\end{tabular}

Rekapitulasi hasil validasi ahli terhadap bahan ajar dengan kriteria baik dan sangat baik maka bahan ajar yang dikembangkan valid.

Tabel 2. Rekapitulasi Nilai Rata-rata Validasi

\begin{tabular}{lll}
\hline Perangkat & $\begin{array}{l}\text { Teknik Penulisan } \\
\text { dan tata bahasa }\end{array}$ & Isi Bahan Ajar \\
\hline Rata-rata validasi & 4,74 & 4,36 \\
Kriteria & Sangat Baik & Baik \\
\hline
\end{tabular}

\section{Hasil uji coba soal}

Uji coba butir soal tes kemampuan berpikir kritis dilakukan untuk mendapatkan validitas, reliabilitas, tingkat kesukaran butir soal, dan daya pembeda. Uji coba dilakukan di kelas C pada tanggal 16 Mei 2018. Jumlah mahasiswa kelas C sebanyak 38 mahasiswa. Rekap analisis hasil uji coba butir soal dapat dilihat pada Tabel 3 berikut.

Tabel 3. Rekap Hasil Uji Coba Butir Soal

\begin{tabular}{|c|c|c|c|c|c|c|}
\hline $\begin{array}{l}\text { No } \\
\text { Soal }\end{array}$ & rhitung & Validitas & $\begin{array}{c}\text { Tingkat } \\
\text { Kesukaran }\end{array}$ & thitung & $\begin{array}{c}\text { Daya } \\
\text { Pembeda }\end{array}$ & Keterangan \\
\hline 1 & 0,6057 & Valid & Sulit & 2,5356 & Signifikan & Dipakai \\
\hline 2 & 0,6088 & Valid & Mudah & 4,1053 & Signifikan & Dipakai \\
\hline 3 & 0,1603 & $\begin{array}{l}\text { Tidak } \\
\text { Valid }\end{array}$ & Mudah & 1,0000 & $\begin{array}{c}\text { Tidak } \\
\text { Signifikan }\end{array}$ & Tidak Dipakai \\
\hline 4 & 0,5549 & Valid & Sedang & 3,1820 & Signifikan & Dipakai \\
\hline 5 & 0,3274 & $\begin{array}{l}\text { Tidak } \\
\text { Valid }\end{array}$ & Sedang & 1,6119 & $\begin{array}{c}\text { Tidak } \\
\text { Signifikan }\end{array}$ & Tidak Dipakai \\
\hline 6 & 0,8690 & Valid & Sulit & 18,4545 & Signifikan & Dipakai \\
\hline 7 & 0,5734 & Valid & Sedang & 3,1820 & Signifikan & Dipakai \\
\hline 8 & 0,3203 & $\begin{array}{l}\text { Tidak } \\
\text { Valid }\end{array}$ & Sulit & 1,3270 & $\begin{array}{c}\text { Tidak } \\
\text { Signifikan }\end{array}$ & Tidak Dipakai \\
\hline
\end{tabular}

\section{Hasil uji data awal}

Hasil uji data awal yang meliputi uji normalitas data kelas A (kelas eksperimen) dan uji normalitas data kelas B (kelas kontrol), uji homogenitas varians, uji kesamaan ratarata. Hasil ujinya dapat dilihat pada Tabel 4 berikut. 
Tabel 4. Uji Normalitas Kelas Eksperimen

\begin{tabular}{|c|c|c|c|r|r|c|}
\hline \multicolumn{1}{|c|}{ Tests of Normality } \\
\cline { 2 - 8 } & \multicolumn{2}{|c|}{ Kolmogorov-Smimove } & \multicolumn{3}{c|}{ Shapiro-Wilk } \\
\cline { 2 - 7 } & Statistic & df & Siq. & Statistic & df & Siq. \\
\hline nilai_kelasA & .138 & 37 & .072 & .946 & 37 & .074 \\
\hline
\end{tabular}

a. Lilliefors Significance Correction

Berdasarkan Tabel 4 di atas, didapatkan bahwa nilai kelas A berdistribusi normal (bisa dilihat pada kolom Sig. Jika nilainya $>0.05$ berarti data berdistribusi normal). Pada Gambar 1 di atas nilai Sig. pada kolom Kolmogorov-Smirnov mempunyai nilai 0.072 berarti lebih besar dari 0.05 dan pada kolom Sig. Shapiro-Walk bernilai 0.074 juga lebih besar dari 0.05 .

Tabel 5. Uji Normalitas Kelas Kontrol

\begin{tabular}{|c|c|c|c|c|c|c|}
\hline \multirow{2}{*}{} & \multicolumn{3}{|c|}{ Kosts of Normality } \\
\cline { 2 - 8 } & Statistic & df & \multicolumn{1}{c|}{ Siq. } & Statistic & df & Sig. \\
\hline nilai_kelasB & .142 & 37 & .059 & .958 & 37 & .171 \\
\hline
\end{tabular}

a. Lilliefors Significance Correction

Berdasarkan Tabel 5 di atas, didapatkan bahwa nilai kelas B berdistribusi normal (bisa dilihat pada kolom Sig. Jika nilainya $>0.05$ berarti data berdistribusi normal). Pada Gambar 2 di atas nilai Sig. pada kolom Kolmogorov-Smirnov mempunyai nilai 0.059 berarti lebih besar dari 0.05 dan pada kolom Sig. Shapiro-Walk bernilai 0.171 juga lebih besar dari 0.05 .

Tabel 6. Uji Homogenitas

\begin{tabular}{|c|c|c|c|c|c|}
\hline & & $\begin{array}{l}\text { Levene } \\
\text { Statistic }\end{array}$ & df1 & $\mathrm{df2}$ & Sig. \\
\hline \multirow[t]{4}{*}{ nilai_AB } & Based on Mean & 3.489 & 1 & 72 & .066 \\
\hline & Based on Median & 2.743 & 1 & 72 & .102 \\
\hline & $\begin{array}{l}\text { Based on Median and } \\
\text { with adjusted df }\end{array}$ & 2.743 & 1 & 63.838 & .103 \\
\hline & Based on trimmed mean & 3.546 & 1 & 72 & .064 \\
\hline
\end{tabular}

Berdasarkan Tabel 6 di atas, didapatkan bahwa nilai kelas A dan B mempunyai varians homogen (bisa dilihat pada kolom Sig. Jika nilainya $>0.05$ berarti varian homogen). 
Tabel 7. Uji Beda Rata-Rata

\begin{tabular}{|c|c|c|c|c|c|c|c|c|c|c|}
\hline \multicolumn{11}{|c|}{ Independent Samples Test } \\
\hline & & \multicolumn{2}{|c|}{$\begin{array}{l}\text { Levene's Test for Equality of } \\
\text { Variances }\end{array}$} & \multicolumn{7}{|c|}{ t-test for Equality of Means } \\
\hline & & \multirow[b]{2}{*}{$\mathrm{F}$} & \multirow[b]{2}{*}{ Sig. } & \multirow[b]{2}{*}{$t$} & \multirow[b]{2}{*}{$\mathrm{df}$} & \multirow[b]{2}{*}{ Sila (2-tailed) } & \multirow[b]{2}{*}{$\begin{array}{c}\text { Mean } \\
\text { Difference }\end{array}$} & \multirow[b]{2}{*}{$\begin{array}{l}\text { Std. Error } \\
\text { Difference }\end{array}$} & \multicolumn{2}{|c|}{$\begin{array}{l}\text { 95\% Confidence Interval of the } \\
\text { Difference }\end{array}$} \\
\hline & & & & & & & & & Lower & Upper \\
\hline nilai_AB & $\begin{array}{l}\text { Equal variances } \\
\text { assumed }\end{array}$ & 3.489 & .066 & 3.505 & 72 & .001 & 12.892 & 3.678 & 5.559 & 20.224 \\
\hline & $\begin{array}{l}\text { Equal variances not } \\
\text { assumed }\end{array}$ & & & 3.505 & 65.521 & .001 & 12.892 & 3.678 & 5.547 & 20.237 \\
\hline
\end{tabular}

Berdasarkan Tabel 7 di atas, uji beda rata-rata diperoleh data bahwa terdapat perbedaan hasil belajar antara kelas A dan kelas B.

\section{Hasil uji data akhir}

a) Uji ketuntasan individu dan klasikal

Uji ketuntasan individu digunakan untuk mengetahui ketercapaian ketuntasan mahasiswa mata kuliah kalkulus vektor secara individu. Dikatakan tuntas apabila kemampuan berpikir kritis secara individu minimal mencapai KKM yang sudah ditentukan yaitu 70 mendapatakan nilai $\mathrm{B}(\geq 65)$. Dari data yang diperoleh pada kelas eksperimen 35 mahasiswa sudah tuntas dan 2 mahasiswa dinyatakan belum tuntas, sedangkan pada kelas kontrol 23 mahasiswa sudah tuntas dan 14 mahasiswa belum tuntas. Perhitungan selengkapnya tentang ketuntasan belajar individu kelas eksperimen dan kontrol sebagai berikut.

Dalam penelitian ini apabila proporsi mahasiswa yang mendapatkan nilai minimal sama dengan 65 sebanyak 79,5\% maka dapat dikatakan bahwa belajar di kelas ini dinyatakan tuntas. Ketuntasan belajar disini adalah ketuntasan terhadap kemampuan berpikir kritis mahasiswa. Uji ketuntasan belajar diambil dari nilai tes pada akhir pembelajaran. Uji ketuntasan klasikal digunakan uji proporsi satu pihak. Hipotesis statistiknya sebagai berikut (Arifin, 2011).

$\mathrm{H}_{0}: \pi \leq 0,795$ (proporsi mahasiswa yang tuntas individu kurang dari atau sama dengan $79,5 \%)$

$\mathrm{H}_{1}: \pi>0,795$ (proporsi mahasiswa yang tuntas individu lebih dari 79,5\%)

Hasil uji ketuntasan klasikal dapat dilihat pada Tabel 8 berikut.

Tabel 8. Hasil Uji Ketuntasan Klasikal

\begin{tabular}{ccccc}
\hline Kelas & $\mathbf{N}$ & Persentase ketuntasan $(\boldsymbol{\pi})$ & Zhitung & Ztabel \\
\hline Eksperimen & 37 & $94 \%$ & 2,276 & 1,96 \\
Kontrol & 37 & $62 \%$ & $-2,609$ & 1,96 \\
\hline
\end{tabular}


Tolak Ho jika $z_{\text {hitung }} \geq z_{\text {tabel }}$. Pada kelas eksperimen didapatkan zhitung yaitu 2,276 dan $\mathrm{Z}_{\text {tabel }}$ yaitu 1,96 dengan tingkat kesalahan $5 \%$ maka $\mathrm{H}_{0}$ ditolak, sehingga bisa disimpulkan bahwa proporsi mahasiswa pada kelas eksperimen yang tuntas individu lebih dari 79,5\%. Pada kelas kontrol didapatkan $\mathrm{z}_{\text {hitung }}=-2,609$ dan $\mathrm{z}_{\text {tabel }}$ yaitu 1,96 dengan tingkat kesalahan 5\% maka $\mathrm{H}_{0}$ diterima, sehingga bisa disimpulkan bahwa proporsi mahasiswa pada kelas kontrol yang tuntas individu kurang atau sama dengan 79,5\%.

b) Uji pengaruh antara sikap dan respon mahasiswa terhadap kemampuan berpikir kritis.

Untuk mengetahui adanya pengaruh antara sikap dan respon mahasiswa berpengaruh terhadap kemampuan berpikir kritis matematis mahasiswa sebagai kriteria efektivitas pembelajaran, digunakan uji statistik regresi linier ganda. Dalam penelitian ini uji pengaruh menggunakan program SPSS 18 dengan output sebagai pada Tabel 9 berikut.

Tabel 9. Hasil Uji Pengaruh

Model Summary

\begin{tabular}{ccccc}
\hline Model & $\mathbf{R}$ & R Square & $\begin{array}{c}\text { Adjusted R } \\
\text { Square }\end{array}$ & $\begin{array}{c}\text { Std Error of } \\
\text { the Estimate }\end{array}$ \\
\hline 1 & $.789^{\mathrm{a}}$ & .623 & .602 & 5.422 \\
\hline
\end{tabular}

a. Predictors: (Constant), respon mahasiswa, sikap belajar mahasiswa

Dari Tabel 9 diperoleh nilai $\mathrm{R}^{2}=0.623=62.3 \%$. Nilai tersebut menunjukkan bahwa variasi variabel kemampuan berpikir kritis (y) dapat dijelaskan oleh variabel sikap belajar mahasiswa $\left(\mathrm{x}_{1}\right)$ dan variabel respon mahasiswa $\left(\mathrm{x}_{2}\right)$ secara bersama-sama sebesar $62.3 \%$.

Tabel 10. Hasil Uji Kelinearan

\begin{tabular}{cccccc}
\multicolumn{7}{c}{ ANOVA $^{\mathbf{b}}$} \\
\hline Model & $\begin{array}{c}\text { Sum of } \\
\text { Squares }\end{array}$ & Df & $\begin{array}{c}\text { Mean } \\
\text { Square }\end{array}$ & F & Sig. \\
\hline 1 Regression & 1701.305 & 2 & 850.652 & 28.933 & $.000^{\mathbf{a}}$ \\
Residual & 1029.037 & 35 & 29.401 & & \\
Total & 2730.342 & 37 & & & \\
\hline
\end{tabular}

a. Predictors: (Constant), respon mahasiswa, sikap belajar mahasiswa

b. Dependent Variable: berpikir kritis

Dari Tabel 10 diperoleh nilai $F=28.933$ sig $=0.000$. Artinya $\mathrm{Sig}=0.000=0 \%<5 \%$ berarti tolak $\mathrm{H}_{0}$ dan terima $\mathrm{H}_{1}$. Jadi persamaan tersebut linier atau sikap belajar mahasiswa $\left(\mathrm{x}_{1}\right)$ dan respon mahasiswa $\left(\mathrm{x}_{2}\right)$ secara bersama-sama berpengaruh secara positif terhadap kemampuan berpikir kritis siswa (y). 
Tabel 11. Hasil Uji Keberartian

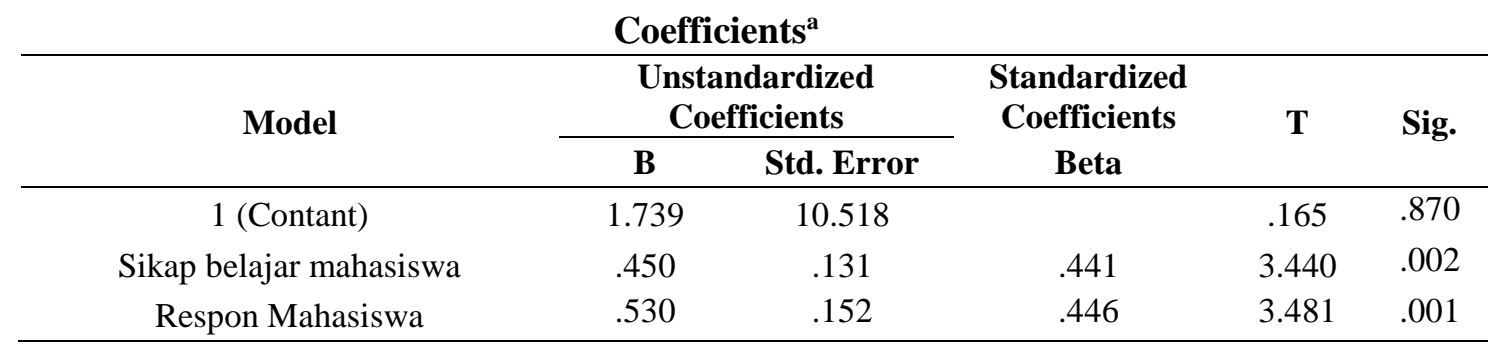

a. Dependent Variable: berpikir kritis

Dari Tabel 11 diperoleh nilai $\mathrm{a}=1.739 ; \mathrm{b}=0.450 ; \mathrm{c}=0.530$. Jadi persamaan regresinya: $\hat{y}=a+b x_{1}+c x_{2}=1.739+0.450 x_{1}+0.530 x_{2}$

c) Uji beda rata-rata dan analisis peningkatan tes kemampuan berpikir kritis.

Pengujian selanjutnya adalah untuk membedakan rata-rata hasil belajar mahasiswa dalam pembelajaran dengan pengembangan bahan ajar dengan rata-rata hasil belajar mahasiswa dalam pembelajaran biasa (tanpa menggunakan pengembangan bahan ajar). Hasil pengujiannya dapat dilihat pada Tabel 12 berikut.

Tabel 12. Hasil Uji Perbedaan Dua Rata-Rata

\begin{tabular}{lllllll}
\hline No. & Kelas & $\mathbf{N}$ & $\overline{\mathbf{X}}$ & $\mathbf{s}^{\mathbf{2}}$ & $\mathbf{t}_{\text {hitung }}$ & $\mathbf{t}_{\text {table }}$ \\
\hline 1. & Eksperimen & 37 & 80,8684 & 73,7930 & \multirow{2}{*}{4,4253} & \multirow{2}{*}{1,9935} \\
2. & Kontrol & 37 & 72,0833 & 71,9643 & & \\
\hline
\end{tabular}

\section{Hipotesis:}

$\mathrm{H}_{0}: \mu_{1} \leq \mu_{2} \quad$ (nilai rata-rata kelas eksperimen kurang dari atau sama dengan kelas kontrol)

$\mathrm{H}_{1}: \mu_{1}>\mu_{2} \quad$ (nilai rata-rata kelas eksperimen lebih dari kelas kelas kontrol)

Berdasarkan perhitungan uji beda dua rata-rata diperoleh $t_{\text {hitung }}=4,4253$ dengan $d k=37+37-2=72$ dan taraf signifikan 5\%, dari daftar distribusi student diperoleh $t_{\text {tabel }}=1,9935$. Karena $\mathrm{t}_{\text {hitung }}>\mathrm{t}_{\text {tabel }}$ maka $\mathrm{H}_{\mathrm{o}}$ ditolak sehingga rata-rata kelas eksperimen lebih baik dibandingkan dengan kelas kelas kontrol.

Untuk menguji peningkatan kemampuan berpikir kritis digunakan uji-t berpasangan. Kegunaan dari uji-t berpasangan (paired t-test) adalah untuk menguji apakah rata-rata dua sampel yang berpasangan sama/berbeda. Sebelum melakukan analisis data dengan uji-t berpasangan, terlebih dahulu kita uji kenormalannya.

Hipotesis :

$\mathrm{H}_{0}: \mu_{\mathrm{B}}=0$ (tidak ada perbedaan antara kemampuan berpikir kritis awal dengan kemampuan berpikir kritis akhir )

$\mathrm{H}_{1}: \mu_{\mathrm{B}} \neq 0 \quad$ (ada perbedaan antara kemampuan berpikir kritis awal dengan kemampuan berpikir kritis akhir) 
Tabel 13. Hasil Uji t berpasangan

\begin{tabular}{cccccc}
\hline Kelas & $\mathbf{N}$ & $\overline{\mathbf{B}}$ & $\mathbf{S}$ & $\mathbf{t}_{\text {hitung }}$ & $\mathbf{t}_{\text {table }}$ \\
\hline Eksperimen & 37 & 11 & 7,1022 & 9,43 & 2,03 \\
Kontrol & 37 & 0 & 9,602 & 0,28 & 2,03 \\
\hline
\end{tabular}

Berdasarkan perhitungan uji-t berpasangan pada kelas eksperimen diperoleh diperoleh $t_{\text {hitung }}=9,43$ dan diperoleh $\mathrm{t}_{\text {tabel }}=2,03$. Karena $\mathrm{t}_{\text {hitung }}>\mathrm{t}_{\text {tabel }}$, maka Ho ditolak berarti ada perbedaan antara kemampuan berpikir kritis awal dengan kemampuan berpikir kritis akhir. Pada kelas kontrol diperoleh diperoleh $t_{\text {hitung }}=0,28$ dan diperoleh $\mathrm{t}_{\text {tabel }}=2,03$. Karena $t_{\text {hitung }}<t_{\text {tabel }}$ maka Ho diterima berarti tidak ada perbedaan antara kemampuan berpikir kritis awal dengan kemampuan berpikir kritis akhir.

\section{SIMPULAN DAN SARAN}

Berdasarkan hasil penelitian dan pembahasan dapat disimpulkan bahwa pengembangan bahan ajar telah melalui proses validasi dan dinyatakan memenuhi validasi isi dan konstruk yang ditetapkan oleh para ahli, sehingga dapat dinyatakan bahwa bahan ajar yang dikembangkan dalam penelitian ini bersifat valid. Hasil uji coba menyatakan bahwa pembelajaran dengan bahan ajar yang dikembangkan berlangsung efektif. Pembelajaran yang efektif dinyatakan dengan empat hal, yaitu: 1) mahasiswa yang menggunakan bahan ajar pembelajaran yang dikembangkan tuntas belajar secara individu dan klasikal, 2) rata-rata nilai mahasiswa di kelas eksperimen lebih baik dari pada kelas kontrol, 3) adanya pengaruh antara sikap dan respon belajar mahasiswa terhadap kemampuan berpikir kritis, dan 4) terjadi peningkatan kemampuan berpikir kritis pada kelas yang menggunakan pengembangan bahan ajar.

Saran yang dapat disampaikan adalah perlunya dikembangkan bahan ajar di setiap mata kuliah sehingga dapat memperbaiki sikap dan respon belajar mahasiswa dalam mengikuti pembelajaran di kelas (tidak mudah bosan, karena pembelajaran akan lebih bervariasi).

\section{DAFTAR RUJUKAN}

Abdullah, In Hi. (2013). Berpikir Kritis Matematik. Delta-Pi: Jurnal Matematika dan Pendidikan Matematika ISSN 2089-855X Vol. 2, No. 1, April 2013 
Anderson, T. et al. (2004). Critical Thinking, Cognitive Presence, Computer Cenferencing in Distance Learning. [Online]. Tersedia: http://www.communityofinquiry.com [16 Desember 2018].

Depdiknas. (2004). Kurikulum Standar Kompetensi Matematika Sekolah Menengah Pertama Dan Madrasah Tsanawiyah. Jakarta: Depdiknas

Ennis, R. H. (1985). "Practical Strategies for the Direct Teaching of Thinking Skill. In A.L. Costa (ed)". Developping Mind: A Resource Book for Teaching Thinking. Alexandria: ASCD, 43-45

Facione, P. A. (2011). Critical thinking: What It is and Why It Counts. Millbrae, CA: Measured Reasons and The California Academic Press

Glazer, E. (2004). Using Web Sources to Promote Critical Thinking in High School Mathematics. [Online]. Tersedia: http//www. Math.unipa.it/ grim. [26 Januari 2013]

Gokhale, A. (1995). "Collaborative Learning Enhances Critical Thinking". Article ejournal. Volume 7, Number 1. Pp 2.

Hassoubah, I. J. (2008). Mengasah Pikiran Kreatif Dan Kritis Disertai Ilustrasi Dan Latihan. Bandung: Nuansa

Khodijah, Y. (2006). Psikologi Belajar. Palembang: IAIN Raden Fatah Press

Krulik, S. \& Rudnick, J. A. (1995). The New Sourcebook for Teaching Reasoning and Problem Solving in Elementary School. Massachusetts: Allyn and Bacon, A. Simon \&sSchucter Company

Martomidjojo, R. (2018). Berpikir Kritir dalam Pembelajaran. http://russamsimartomidjojocentre.blogspot.com. Diakses pada tanggal 15 Oktober 2018.

Meyers. (1986). Teaching Students to Think Critically. San Francisco: Jossey-Bass Inc., Publishers

Salinan oleh Bambang Sutedjo untuk sesama Tenaga Pendidik guna Keberhasilan KTSP. Pengembangan Bahan Ajar dan Media.

Schafersman, S. O. (1991). An Introduction to Critical Thinking. www. Freeinquiry.com/critical-thinking

Spiegel, M. R. (1985). Analisis Vektor dan suatu pengantar Analisis Tensor. Jakarta: Erlangga. 
Thiagarajan, S., Semmel, D. S., dan Semmel, M. I. (1974). Instructional Development for Teachers of Exceptional Children. Minneapolis, Minnesota: Leadership Training Institute/Special Education, University of Minnesota.

Thompson, C. (2011). "Critical Thinking across the Curriculum: Process over Output". International Journal of Humanities and Social Science. Vol. 1 No. 9. Pp 1-2.

Wahab. (1996). Pendidikan PPKN. Jakarta: Depdikbud. 